\title{
An Empirical Study of the Influence of Trade and Human Capital on Shanghai's Transformation and Development
}

\author{
Lin Sun \\ Hao-yu Wang \\ Can Min \\ Institute of Applied Economy \\ Shanghai Academy of Social Science
}

\begin{abstract}
The stability and improvement of the level of TFP is the decisive factor for the sustainable development of the regional economy. Quantitatively studying the relationship between domestic and foreign trade, human capital and TFP, it is helpful to analyze the actual impact of domestic and foreign trade and human capital on Shanghai's transformation and development, and explore the specific policy options of the "Innovation-driven, transformational development" strategy. The results show that international trade increased the level of TFP in the early part of this century. After the global financial crisis in 2008, the model of Shanghai's economic development faced transformation. For a long time, the Shanghai government has implemented the talent introduction policy, the human capital has been improved, and the negative impact of the shrinking international trade on TFP has been hedged. To a certain degree, the Shanghai economy has been successfully transformed from the export-driven model to an innovation-driven model by endogenous factors such as human capital.
\end{abstract}

Keywords: Transformation Development, Shanghai Economy, TFP, Trade, Human Capital

\section{Introductionand literature review}

Shanghai aims to build itself into an international center of economy, finance, trade, and shipping as well as an innovation center of science and technology with global influence. In order to accomplish this objective, Shanghai has vigorously promoted the implementation of the strategy of "innovation-driven, transformational development" since 2000. By constantly enhancing the opening to the outside world and introducing international and domestic human capital, Shanghai tries the best to improve its total factor productivity and realize the transformation of the economic development model, which will promote the long-term sustainable development of Shanghai's economic. There are many factors influencing regional economic growth, including quantitative factor input and total factor productivity (TFP), while regional trade and human capital investment have an important impact on the total factor productivity. Trade openness exerts a positive effect on regional economic growth while promoting spatial convergence and divergence at the same time and the effect exhibits spatial heterogeneity which depends on the different development levels of the regional economy, infrastructure construction and human capital (Xiong, Wei, \& Yang, 2012). Mao \& Sheng (2011) and Li et al. (2013) point out that through export trade and market contact, the tradable sector can obtain new technologies, new designs, and advice from foreign consumers on improving product quality, that is, the productivity of the tradable sector will be enhanced by learning with export. What's more, they mention that the open economy can make the tradable sector face fierce competition from the international market and the tradable sector has to maintain its market share by increasing R\&D investment, improving operational efficiency, improving management and improving product quality to tackle the competitive pressure. They also demonstrate that exports can expand the product market, and the expansion of production scale will cause economies of scale and technological progress, which can lead to a climbing labor productivity in the trade sector.

In the studies of total factor productivity, Romer (1986) and Lucas (1988) establish endogenous growth theory and believe that human capital is one of the key factors affecting total factor productivity. Nelson and Phelps (1966) conclude that human capital mainly affects total factor productivity in two ways: one is to directly influence productivity by determining a country's technological innovation capability, and the other is to impact technological imitation and technology diffusion speed. Xu et al. (2006) indicate that the accumulation of human capital affects the TFP more directly than economic growth and human capital affects economic growth through affecting the TFP. As is argued by Liu and $\mathrm{Hu}$ (2009), human capital affects regional economic growth by influencing the total factor productivity in the region, realizing the accumulation of factors and affecting the path of economic growth. 
Wei $(2009,2010)$ shows that, to some extent, there are clear threshold characteristics between human capital and TFP growth. In provinces with economic indicators beyond a certain threshold value, the effects of human capital on productivity growth are stronger. The stability and improvement of TFP is the decisive factor for the long-term sustainable development of the regional economy. This paper estimates Shanghai's total factor productivity and analyzes the actual impact of domestic and foreign trade as well as human capital on Shanghai's transformation and development by quantitatively studying the relationship between these factors and TFP. Using the result, we explore the specific policies for the "innovation-driven, transformational development" strategy.

\section{The estimation of TFP in Shanghai}

According to different data scopes, TFP can be estimated by data envelopment analysis (DEA), stochastic frontier analysis (SFA), growth accounting method, growth regression method or Solow's residual estimate (Lu \& Lian, 2012). The DEA method is based on the micro-level data of the enterprise, mainly to estimate the total factor productivity of the enterprise (Tian et al., 2017). The SFA method can be used for macro or microdata, and the growth accounting method, the growth regression method, as well as Solow's residual estimate, are based on macro data. This paper uses the Solow's residual estimate and the growth regression method to measure total factor productivity because we use 17 years of macro data from 2000 to 2016 without the endogenous problem brought about by the enterprise microdata. Since the purpose of the study is to make an attribution analysis of Shanghai's TFP growth, Solow's residual estimate and the growth regression method completely fulfill the requirement. We select the time series data from 2000 to 2016 of GDP, fixed assets investment, labor and human capital, import and export, and price indices of Shanghai. All the data are annual and were taken from the Statistical Yearbook for Shanghai, 2001-2017. We also need to convert the nominal variables such as GDP and fixed asset investment into real variables based on the relevant price index. In the actual process, we use the Shanghai GDP index to calculate the actual total output and the fixed asset price index to calculate the actual fixed capital investment, regarding 2000 as the base period. When calculating the fixed capital stock, we use the perpetual inventory method, which is $\mathrm{K}_{\mathrm{t}}=\mathrm{I}_{\mathrm{t}} / \mathrm{P}_{\mathrm{t}}+(1-\delta) \mathrm{K}_{\mathrm{t}-1}$. According to Zhang et al. (2004), we select $\delta=9.6 \%$, which means that the capital stock of the base period is calculated by dividing the fixed-asset investment amount in the base period by $9.6 \%$. The result of capital stock is similar to the Shanghai capital stock in 2000 calculated by Shan (2008). As for the labor force, the total number of social workers is used as the labor input for calculating total factor productivity. Based on these data (Table 1), we calculated the Shanghai TFP time series by macro-level Solow's residual estimate.

The statistical description indications are shown in Table 1, which are used in analyzing the impact of net outflow, net export and human capital on TFP in Shanghai by econometric analysis. The capital intensity is expressed in terms of the per capita fixed capital stock, that is, the real fixed capital stock divides by the number of employees in all industries. As a result of the inability to obtain data on the number of years of education of employees in various industries, as an alternative, the proportion of scientific and technological personnel can be regarded as human capital (Xia, 2010). In this paper, we use the number of people engaged in scientific and technological activities in the industrial enterprises above the state-designated scale, divided by the number of employees in all industries to obtain human capital variables. The model for measuring TFP is as follows:

$$
\ln (\mathrm{GDP})=\ln \left(\mathrm{TFP}_{\mathrm{a}}\right)+\alpha \ln \left(\mathrm{K}_{\mathrm{a}}\right)+\beta \ln (\mathrm{L})
$$

In Equation (1), $\mathrm{K}_{\mathrm{a}}$ is the real fixed capital stock, $\mathrm{L}$ is the supply of labor, $\mathrm{TFP}_{\mathrm{a}}$ is the TFP obtained by the OLS regression method. The calculation results are shown in Figure 1.

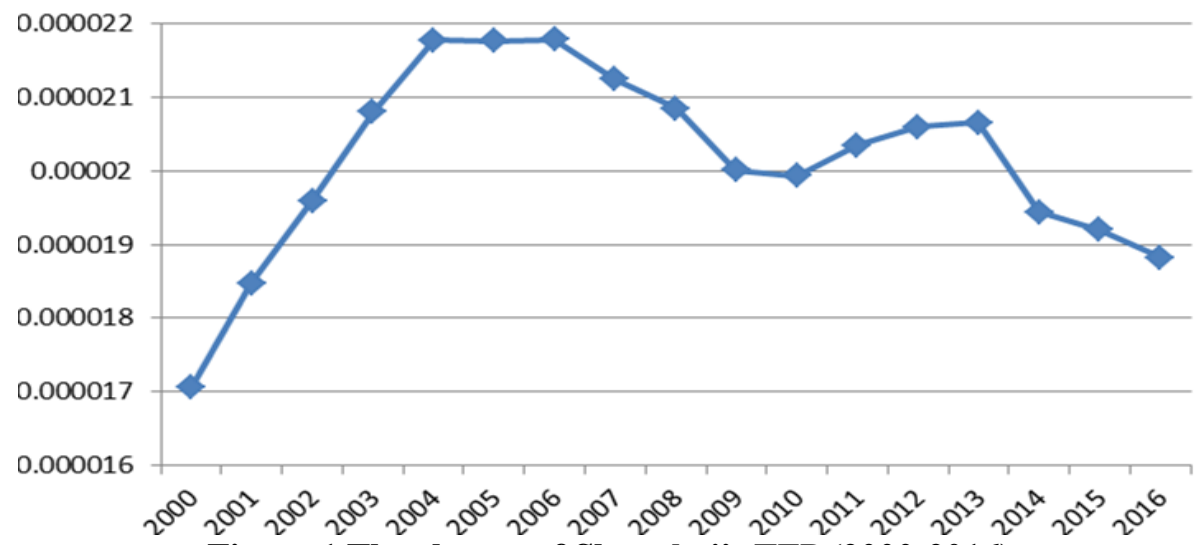

Figure 1 The change of Shanghai's TFP (2000-2016) 
Table 1 Data used to measure total factor productivity

\begin{tabular}{|c|c|c|c|c|c|c|}
\hline Year & $\begin{array}{l}\text { Real GDP } \\
(0.1 * \text { billion } \\
\text { yuan })\end{array}$ & $\begin{array}{l}\text { Real fixed capital } \\
\operatorname{stock}\left(\mathrm{K}_{\mathrm{a}} \text { 、 }\right. \\
0.1 \text { *billion yuan })\end{array}$ & $\begin{array}{l}\text { Human } \\
\text { capital }\end{array}$ & $\begin{array}{l}\text { Capital intensity } \\
\left(10^{*} \text { billion }\right. \\
\text { yuan/million } \\
\text { people })\end{array}$ & $\begin{array}{l}\text { Net export } \\
(0.1 * \text { billi } \\
\text { on yuan })\end{array}$ & $\begin{array}{l}\quad \text { Net } \\
\text { outflow } \\
(0.1 * \text { billio } \\
\text { n yuan })\end{array}$ \\
\hline 2000 & 4812 & 18697 & 0.0271 & 25.1 & -331 & 688 \\
\hline 2001 & 5317 & 18883 & 0.0234 & 25.1 & -467 & 933 \\
\hline 2002 & 5923 & 19235 & 0.0226 & 24.3 & -708 & 1387 \\
\hline 2003 & 6652 & 19760 & 0.0216 & 24.3 & -1277 & 2319 \\
\hline 2004 & 7603 & 20660 & 0.0218 & 24.7 & -1075 & 2422 \\
\hline 2005 & 8477 & 21862 & 0.0228 & 25.3 & -400 & 1670 \\
\hline 2006 & 9562 & 23290 & 0.0227 & 26.3 & -27 & 1095 \\
\hline 2007 & 11015 & 24925 & 0.0222 & 24.3 & 371 & 533 \\
\hline 2008 & 12084 & 26417 & 0.0219 & 25.1 & 1150 & -997 \\
\hline 2009 & 13099 & 28254 & 0.0318 & 26.5 & 416 & -13 \\
\hline 2010 & 14435 & 29789 & 0.0307 & 27.3 & -494 & 2484 \\
\hline 2011 & 15634 & 30730 & 0.0340 & 27.8 & -1153 & 5844 \\
\hline 2012 & 16806 & 31746 & 0.0349 & 28.5 & -1461 & 8519 \\
\hline 2013 & 18117 & 32951 & 0.0379 & 29.0 & -2039 & 10978 \\
\hline 2014 & 19403 & 34294 & 0.0330 & 25.1 & -2830 & 15208 \\
\hline 2015 & 20761 & 35908 & 0.0329 & 26.4 & -3600 & 18629 \\
\hline 2016 & 22194 & 37698 & 0.0365 & 27.6 & -4442 & 23624 \\
\hline
\end{tabular}

\section{The impact of international and domestic trade on Shanghai's TFP}

As Figure 1 indicates, Shanghai's TFP has experienced rising, falling, and tending to be relatively stable since 2000. Both the demand range and the input range factors will affect the fluctuation of the TFP to some extent. This study selects net outflow (DC) and net export (NEX) which can reflect the changes in external demand, and the human capital $(\mathrm{H})$ which can reflect the input of non-quantitative factors as independent variables to analysis the relationship between them and the TFP of Shanghai. We use the following regression model:

$$
\mathrm{TFP}=\alpha_{1} \mathrm{DC}+\alpha_{2} \mathrm{NEX}+\mathrm{H}+\mathrm{D}+\mathrm{D}_{\mathrm{DC}}+\mathrm{D}_{\mathrm{NEX}}+\mathrm{D}_{\mathrm{H}}+\mathrm{X}(2)
$$

In Equation (2), $\mathrm{D}$ is a time dummy variable indicating if the year is after $2008 . \mathrm{D}_{\mathrm{DC}}, \mathrm{D}_{\mathrm{NEX}}$, and $\mathrm{D}_{\mathrm{H}}$ are the interaction terms of the time dummy variable (D) and net outflow (DC), net export (NEX), and human capital (H), respectively. X is a control variable in which the capital intensity is selected as. We use OLS to gradually regress the above formula, and the results we obtain are shown in Table 2.

As shown in Table 2, net outflow and net export have no significant impact on TFP without the time dummy variable. This can be explained by the fact that in 2008, the dramatic changes in international and domestic trade caused by the global financial crisis have had a structural impact on Shanghai's economic. Total factor productivity, which has been on the rise for the past, showed a downward trend after 2008. So, we need to add a time dummy variable (using 2009 as a time node) to capture this phenomenon. After adding the time dummy variable and two interaction terms, the coefficients of the regression variables become significant (Table 2 TFP-2). The net outflow and the net export of Shanghai before 2009 have a positive impact on Shanghai's TFP. After the time of 2009, the interaction terms make the original variable regression coefficient change from positive to negative. The impacts of Shanghai's net outflow and net export on TFP become negative. Before 2009, the impact of net exports on total factor productivity was greater than the impact of net outflow, reflecting that Shanghai was more inclined to rely on international trade to drive economic growth. The technological changes and the competitive environment changes brought about by international trade had enabled enterprises to continuously improve their products' competitiveness and led to technological advancement and product quality improvement, which had played a positive role in the growth of Shanghai's total factor productivity. 
At the same time, as a developed region in China, Shanghai was in an advantageous position compared with other parts of the country. As a result, products that were traded with other regions had a lower level in technology and competitiveness than those traded on world markets. Domestic goods were more difficult to motivate companies to upgrade their technology and product competitiveness compared to international goods. This phenomenon can explain to a certain extent that why the net outflow which reflects domestic trade demand made less impact on Shanghai's TFP than net export reflecting international trade demand.

Table 2 OLS results for TFP

\begin{tabular}{|c|c|c|c|c|c|}
\hline \multirow{2}{*}{ Variables } & & \multicolumn{4}{|c|}{ TFP } \\
\hline & 1 & 2 & 3 & 4 & 5 \\
\hline $\mathrm{DC}$ & $\begin{array}{c}-6.36 e-11 \\
(-0.31) \\
\end{array}$ & $\begin{array}{c}4.24 \mathrm{e}-09^{* * *} \\
(5.11) \\
\end{array}$ & & $\begin{array}{c}2.95 e-11 \\
(0.11) \\
\end{array}$ & $\begin{array}{c}3.06 \mathrm{e}-09^{* * *} \\
(6.94) \\
\end{array}$ \\
\hline NEX & $\begin{array}{c}7.06 e-11 \\
(0.08)\end{array}$ & $\begin{array}{c}5.74 \mathrm{e}-09^{* * *} \\
(4.72) \\
\end{array}$ & & $\begin{array}{c}3.42 \mathrm{e}-10 \\
(0.32)\end{array}$ & $\begin{array}{c}4.21 \mathrm{e}-09^{* * *} \\
(6.69) \\
\end{array}$ \\
\hline $\mathrm{H}$ & & & $\begin{array}{c}-0.0009078^{* * *} \\
(-4.42) \\
\end{array}$ & $\begin{array}{c}-0.0000508 \\
(-0.52) \\
\end{array}$ & $\begin{array}{c}-0.0004947^{* * *} \\
(-4.52) \\
\end{array}$ \\
\hline $\mathrm{D}$ & & $\begin{array}{c}3.20 \mathrm{e}-06^{* * *} \\
(3.66)\end{array}$ & $\begin{array}{c}-0.0000215^{* * *} \\
(-3.32) \\
\end{array}$ & & $\begin{array}{c}-0.0000152^{* * *} \\
(-4.62) \\
\end{array}$ \\
\hline $\mathrm{D}_{\mathrm{DC}}$ & & $\begin{array}{c}-4.43 e-09^{* * *} \\
(-4.81)\end{array}$ & & & $\begin{array}{c}-3.33 e-09^{* * *} \\
(-6.81)\end{array}$ \\
\hline $\mathrm{D}_{\mathrm{NEX}}$ & & $\begin{array}{c}-6.35 e-09^{* * *} \\
(-2.60)\end{array}$ & & & $\begin{array}{c}-5.15 \mathrm{e}-09^{* * *} \\
(-4.30) \\
\end{array}$ \\
\hline $\mathrm{D}_{\mathrm{H}}$ & & & $\begin{array}{c}0.0009231^{* * *} \\
(3.82) \\
\end{array}$ & & $\begin{array}{c}0.0006876^{* * *} \\
(5.97) \\
\end{array}$ \\
\hline $\mathrm{X}$ & $\begin{array}{c}-0.0000284 \\
(-0.68) \\
\end{array}$ & $\begin{array}{c}-2.18 \mathrm{e}-06 \\
(-0.09)\end{array}$ & $\begin{array}{c}0.0000261 \\
(1.10) \\
\end{array}$ & $\begin{array}{c}-0.000017 \\
(-0.35) \\
\end{array}$ & $\begin{array}{c}1.29 \mathrm{e}-06 \\
(0.947)\end{array}$ \\
\hline Intercept & $\begin{array}{c}0.0000623 \\
(1.01) \\
\end{array}$ & $\begin{array}{c}0.0000206 \\
(0.55) \\
\end{array}$ & $\begin{array}{c}2.58 \mathrm{e}-06 \\
(0.08)\end{array}$ & $\begin{array}{c}0.0000468 \\
(0.66) \\
\end{array}$ & $\begin{array}{c}0.0000277 \\
(1.04) \\
\end{array}$ \\
\hline $\mathrm{R}$ & 0.1293 & 0.7687 & 0.6394 & 0.1487 & 0.9587 \\
\hline
\end{tabular}

(***significant at the $1 \%$ level, $* * 5 \%$ level, $* 10 \%$ level)

Beginning in the second half of 2008, due to the global financial crisis, the global trade demand had shrunk, and the international market demand for Chinese products had declined. Figure 2 and figure 3 show that Shanghai's net export fell rapidly and international demand plummeted, while net outflow rose linearly during this period, which means that Shanghai maintained economic growth by importing a large number of products from international markets and exporting products to other regions of China. The impact of net export and net outflow on TFP, therefore, had changed. The changes in the trading environment had led to a shift from export trade to domestic inter-regional trade, and the status of the domestic market had risen. After 2009, added to the interaction terms respectively, the regression coefficients of net outflow and net export changed from positive numbers to negative values approximately equal to zero, indicating that the transformation of Shanghai's economic structure after 2009 made the impact of international trade on the level of total factor productivity in Shanghai gradually weakened. Shanghai is facing the challenge of transition from an export-oriented economy that relies on the international market to an endogenous-driven economy that relies on internal technological advancement and improved human capital quality.

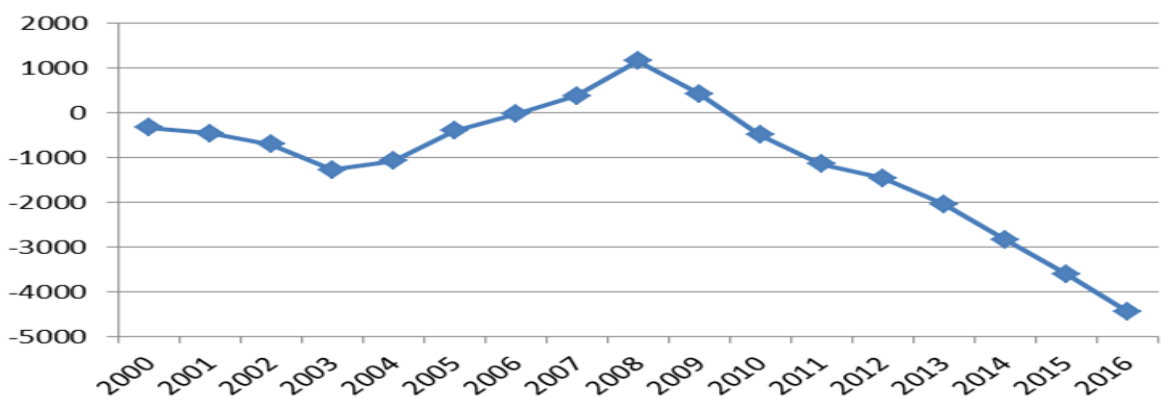

Figure 2 The real value of Shanghai's net export (2000-2016) 


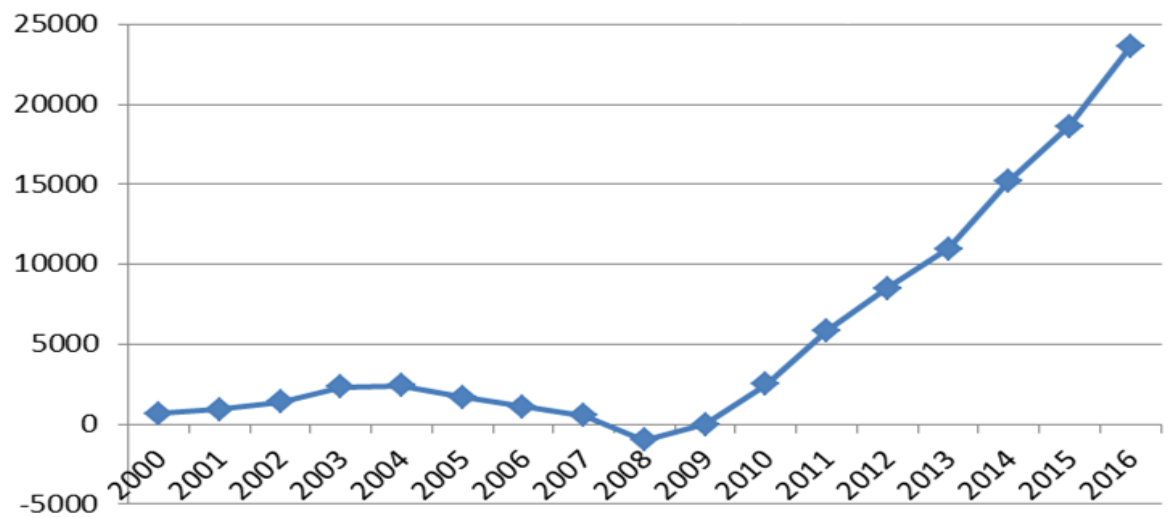

Figure 3 The real value of Shanghai's net outflow (2000-2016)

\section{The impact of human capital on Shanghai's TFP}

As mentioned above, the global demand reduction caused by the global financial crisis in 2008 has had a great impact on Shanghai's economic development. It is inevitable for Shanghai to implement the strategy of "innovation-driven, transformational development". As an important part of the transformation and development strategy, the introduction of non-quantitative factors to promote sustainable economic development, and the introduction of high-end talents to enrich and improve the quality of human capital have become important policy options. In fact, as early as 1984, the Shanghai Municipal Government issued the "Interim Measures for the Transfer of Professional and Technical Cadres from Other Regions". For the first time, it is clearly stated in the policy that talents who are scarce in Shanghai can be introduced from other places (Xie, 2009). After 2005, Shanghai's talent policy targets include high-level talents, ordinary talents, and overseas talents, with high-level talents and overseas talents as the mainstays. The Shanghai Municipal Government formulated "A Number of Rules about Encouraging Overseas Students to Work and Start Businesses in Shanghai" in 2005. In 2015 and 2016, 8 and 14 talent-related policies were intensively introduced, including "the Implementing Measures of Implementing a More Open Domestic Talent Introduction Policy to Serve the Construction of a Scientific and Technological Innovation Center with Global Influence" which was made in November 2015 (Shen et al., 2018). The intensive introduction of talent introduction policy reflects Shanghai's emphasis on introducing excellent and high-level talents to improve the quality of human capital.

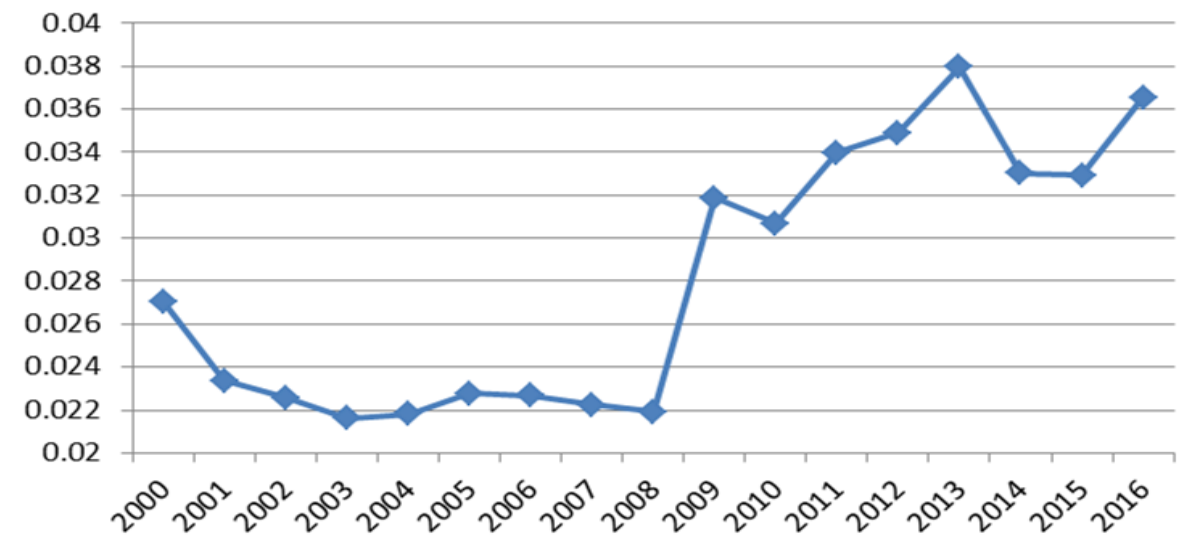

Figure 4 The change of human capital (2000-2016)

By adding time dummy variables (using 2009 as the time node), we examine the impact of human capital on Shanghai's total factor productivity and analyze the role of Shanghai's talent policy for improving human capital quality. It can be noted from Table 2 that the regression coefficient of human capital is negative, while the coefficient of the interaction term of human capital and time dummy variable is positive and has a larger absolute value (Table 2 TFP-3). The negative regression coefficient of human capital indicates that before 2009, Shanghai's human capital and Shanghai's total factor productivity were negatively correlated. The data from Figure 4 reveals that Shanghai's human capital has been declining until 2009. After 2009, Shanghai's human capital has changed to a rising state. While Shanghai's total factor productivity has been rising until 2009, and after 2009, Shanghai's total factor productivity has declined. 
Based on comprehensive consideration of the changes in Shanghai's human capital and TFP and the results of the model (Table 2 TFP-4,5), we can draw a conclusion that the main factor driving the rise of Shanghai's TFP before 2009 is not high-tech enterprises and high-end talents, but international export trade. However, with the sharp decline in international trade demand caused by the global financial crisis in 2008, Shanghai's economic development model gradually began to transform after 2009. Through the multi-dimensional "innovation-driven, transformational development" strategy, Shanghai has implemented policies of actively introducing high-tech enterprises and high-end talents, effectively improving the quality of human capital and enhancing the technological level and competitiveness of enterprises. These policies have played a positive role in maintaining the stability of Shanghai's total factor productivity and promoting Shanghai's economic transformation.

\section{Conclusion and policy implications}

The measurement results of the total factor productivity show the volatility of TFP in Shanghai from 2000 to 2016 from the continuous rise and short-term decline to gradual recovery and stabilization. The empirical research reveals the impact of international trade, domestic trade and human capital on Shanghai TFP changes, which can help to understand the impact on Shanghai's economic transformation and development. In the early part of this century, Shanghai's economic growth relied mainly on international trade, and the international capital and competition brought about by international trade increased Shanghai's total factor productivity. After the global financial crisis in 2008, the shrinking demand for international trade prompted a structural shift in Shanghai's economic growth model. The talent strategies of the Shanghai Municipal Government, containing promoting the introduction of high-end talents at home and abroad, promoting technological innovation of local enterprises, improving technology and competitiveness, and improving human capital levels, gradually worked, which have effectively hedged and alleviated the negative impact of the shrinking international trade on Shanghai's TFP. To a certain extent, Shanghai's economy has achieved a successful transformation from an export-driven model to an "innovation-driven" model driven by endogenous factors such as human capital. The policy implications of the conclusions are that although the spillover effects of capital and technology brought about by international trade contribute to the improvement of TFP and economic growth, overreliance on international trade makes the regional economy subject to changes in the international economic environment, and economic growth tends to lack of stability and sustainability. Endogenous production and technological innovation activities are the continuous driving force for regional economic growth, while human capital is an important support for innovation activities. Therefore, the vigorous introduction of high-level talents at home and abroad is not only an important practice for Shanghai to promote and implement the strategy of "innovation-driven, transformational development", but also a priority policy option for maintaining sustainable development in the future.

\section{References}

Li, X., Chen, Y., and Wang S. (2013). Import, export, and productivity —an empirical analysis based on China's manufacturing firm-level data. Finance \& Trade Economics, 2013 (12): 101-111.

Liu, Z., and Hu, Y. (2009). Human capital, the marginal productivity of factors and regional inequality: a theoretical framework and empirical study. Chinese Journal of Population Science, 2009(3):21-31.

Lu, X., and Lian, Y. (2012). Estimation of the total factor productivity of industrial enterprises in China: 19992007. China Economic Quarterly, 2012 (2): 541-558.

Lucas, R. (1988). On the mechanism of economic development, Journal of Monetary Economy, 103 (1988), pp.759-784.

Mao, Q., and Sheng, B. (2011). Economic opening, regional market integration, and total factor productivity. China Economic Quarterly, 2012(1): 181-210.

Nelson, R. and E Phelps (1966). Investments in humans, technological diffusion and economic growth, American Economic Review, 56 (1966), pp.69-75.

Romer, P. (1986). Increasing return and long-run growth, Journal of Political Economy, 94 (1986), pp.1002-1037.

Shan, H. (2008). Estimating the capital stock of China: 1952-2006. The Journal of Quantitative \& Technical Economics, 2008 (11): 17-31.

Shen, Z., Zhang, Y., and Yu, Y. (2018). Text analysis on Shanghai science and technology talent policy, Technology Intelligence Engineering, 2018 (1): 89-100.

Tian, Y., Lu, S., and Jin, L. (2017). The method, data and the difference of TFP measurement, The Journal of Quantitative \& Technical Economics, 2017 (12): 22-40.

Wei, X. (2009). The dynamic relationship among openness, human capital, and total factor productivity in China. World Economy Studies, 2009 (3): 9-15. 
Wei, X., and Zhang, J. (2010). Threshold effect of human capital on TFP growth: evidence from China. Chinese Journal of Population Science, 2010 (5): 48-57.

Xia, L. (2010). How human capital and R\&D investments influence TFP. The Journal of Quantitative \& Technical Economics, 2010 (4): 78-94.

Xie, Q. (2009). Thirty years of Shanghai talent policy: evolution and innovation. Talent Exploitation, 2009 (4): 8-10.

Xiong, L., Wei, W., and Yang, Y. (2012). The spatial effect of trade openness on regional economic growth: A study based on 1987-2009 spatial panel data in China. China Economic Quarterly, 2012(3): 1037-1058.

Xu, H., Qi, P., and Zhu, S. (2006). Openness, human capital, and total factor productivity: an empirical analysis of the provincial panel data in China. The Journal of World Economy, 2006(12): 3-10.

Zhang, J., Wu, G., and Zhang, J.P. (2004). The estimation of China's provincial capital stock: 1952-2000. Economic Research Journal, 2004 (10): 35-44. 